\title{
Variation in Tree Growth Characteristics, Pilodyn Penetration, and Stress-wave Velocity in 65 Families of Acacia mangium Trees Planted in Indonesia ${ }^{1}$
}

\author{
Fanny HIDAYATI(D) ${ }^{2, \dagger} \cdot$ Ganis LUKMANDARU ${ }^{2} \cdot$ Sapto INDRIOKO ${ }^{2} \cdot$ \\ Sri SUNARTI $^{3} \cdot$ Arif NIRSATMANTO $^{3}$
}

\begin{abstract}
Growth characteristics [stem diameter (D), tree height $(\mathrm{H})$ ] and wood properties [Pilodyn penetration (P) and stress-wave velocity (SWV)] were measured for 65 families of 6-year-old Acacia mangium trees planted in Indonesia, in order to characterize their variation in $\mathrm{D}, \mathrm{H}, \mathrm{P}$, and SWV. Therefore, the correlations between the measured characteristics were also determined, and their significant differences observed. Furthermore, their low to moderate values of narrow-sense heritability was obtained, and the results indicated the characteristics to be genetically controlled in A. mangium. In addition, highly significant positive correlations were observed among the growth characteristics, suggesting a close relationship, while there was no significant association between the growth characteristics and P, as well as SWV, indicating their independent. Therefore, these results demonstrate a potential for the improvement of both growth and wood properties of A. mangium trees, using the appropriate breeding programs. In addition, 18 families showed good performance in $\mathrm{D}$ and $\mathrm{SWV}$, signifying their positive prospect of being considered as plus trees for the next generation breeding cycles.
\end{abstract}

Keywords: Acacia mangium, tree breeding, growth characteristics, pilodyn penetration, stress-wave velocity

\section{INTRODUCTION}

Some fast-growing tree species have been developed in Indonesia, which includes Acacia spp., Eucalyptus spp., Falcataria moluccana, and Gmelina arborea. Acacia mangium has been identified to be the most adaptable in the marginal area when compared to 46 other species tested by the government (Arisman, 2002). In addition, it easily acclimatizes to various types of soil with varying $\mathrm{pH}$, grows rapidly, and also tends to produce good quality timber (Fujimoto et al., 2002; Kim et al., 2009). Hence, it is widely planted in several tropical countries and subtropics, including Malaysia, Vietnam, Bangladesh, and especially in Indonesia (Fujimoto et al., 2002; Kim et al., 2009), where it is one of the prevalent species developed in the forest of industrial plants, as a raw material for pulp and paper (Marsoem, 2004). Meanwhile, other species (including

\footnotetext{
${ }^{1}$ Date Received May 15, 2019, Date Accepted August 23, 2019

2 Faculty of Forestry, Universitas Gadjah Mada, Yogyakarta 55281, Indonesia

${ }^{3}$ Center for Forest Biotechnology and Tree Improvement, Yogyakarta 55582, Indonesia

† Corresponding author: Fanny HIDAYATI (e-mail: fanny_hidayati@ugm.ac.id, ORCID: 0000-0003-0914-4636)
} 
slow-growing types), encompassing three species of styrac wood, Gmelina arborea, teak, Moluccan ironwood, linggua, red meranti, gofasa and Pinus merkusii, wood properties have been investigated (Iswanto et al., 2016; Hidayati et al., 2017a; Hidayati et al., 2017b; Hidayat et al., 2017; Darmawan et al., 2018).

Therefore, the increasing need for solid wood both in construction and furniture worldwide provides opportunities for fast-growing species to be applied as construction materials and furniture, e.g., A. mangium. This also increases its selling price comparably with being a raw material for pulp and paper. Furthermore, the properties both in density and in strength have been widely studied (Fujimoto et al., 2002; Honjo et al., 2005; Kim et al., 2009; Kojima et al., 2009; Matsumoto et al., 2010; Makino et al., 2012). Nugroho et al. (2011) reported about the wood properties of 5 provenances of A. mangium planted in Indonesia, and Hai et al. (2015) stated evidence about its growth characteristics and wood properties in second-generation progeny test planted in Vietnam. Meanwhile, studies on this property from tree breeding programs material, where their quality is one of the important aspects in obtaining superior products (Zobel and van Buijtenen, 1989) are limited. However, several fast-growing species have been investigated, including A. mangium, Falcataria moluccana, A. auriculiformis, and Eucalyptus (Hai et al., 2015; Ishiguri et al., 2007; Hai et al., 2008; Muneri and Raymond, 2000). Therefore, it is expected that an increase in the quality of $A$ mangium wood is improved through these programs.

Non-destruction and semi-destructive techniques for evaluating wood properties are capable of decreasing cost, energy, and time, and these are applied in solid and non-solid wood products (Jeong et al., 2016; Rofii et al., 2016; Hidayat et al., 2017). Moreover, Pilodyn was introduced as a non-destructive assessment method for density within the breeding program (Sprague, 1983; Woods et al., 1995; Hansen, 2000), as its penetration confers a significantly negative correlation (Taylor, 1981; Wei and Borralho, 1997; Wu et al., 2010; 2011b). In addition, the stress-wave velocity (SWV) method is a non-destructive method for evaluating quality, especially based on mechanical properties (Ishiguri et al., 2007), and a significant, positive association exists with standing trees or log and Young's modulus of logs (Ross et al., 1997; Wang et al., 2001; Ishiguri et al., 2007; 2013; Wu et al., 2011b).

This study is, therefore, aimed at characterizing variations in growth parameters [stem diameter (D) and tree height $(\mathrm{H})$ ], and wood properties [Pilodyn penetration (P) and stress-wave velocity (SWV)] in 65 families of A. mangium, planted in a third-generation progeny trial. Furthermore, the relationships prevailing amongst each were also investigated.

\section{MATERIALS and METHODS}

The third-generation progeny trial of $A$. mangium was established in the Forest Research of Alas Ketu, Wonogiri, Central Java province, Indonesia $\left(07^{\circ} 32^{\cdot} \mathrm{S}\right.$ - $\left.110^{\circ} 41 \cdot \mathrm{E}\right)$. This consisted of 65 families, which originated from 8 provenances in Papua New Guinea, and Australia (Table 1), and the set up was established in February 2012. Meanwhile, information on environmental conditions are as follows: the average temperature was $27.22^{\circ} \mathrm{C}$, rainfall $(1,878 \mathrm{~mm} /$ year), the elevation of $141 \mathrm{~m}$ above sea level, climate type C (Schmidt and Ferguson), and soil type was vertisol. In addition, the plantation trial was established using randomized complete block design, with six blocks as replications, and four tree-plots for each family, with a spacing of $4 \times 2$ meters. Furthermore, fertilization was applied two times per year, using NPK up to the point where they were 2-year-old. This process was thinned thrice in the following years: 2015, 2016, and 2017 for retaining one of the best varieties within each tree-plot. 
Variation in Tree Growth Characteristics, Pilodyn Penetration, and Stress-wave Velocity in 65 Families of Acacia mangium Trees Planted in Indonesia

Table 1. Information on the family origin of third-generation progeny trial of Acacia mangium (Sunarti et al., 2012)

\begin{tabular}{cccc}
\hline Provenance & $\begin{array}{c}\text { Total number } \\
\text { of family }\end{array}$ & Family code & $\begin{array}{c}\text { Number of } \\
\text { trees }\end{array}$ \\
\hline \hline Oriomo, PNG & 11 & $1,2,3,4,5,6,45,46,47,48,49$ & 46 \\
Kini, WP & 32 & $7,8,20,21,22,23,24,25,26,27,28,29,30,31,32,33,34,35$, & 137 \\
Wipim, WP & 16 & $36,37,38,39,40,41,42,43,44,53,54,56,57$ & 68 \\
Bimade, PNG & 1 & $9,10,11,12,13,14,15,16,17,18,19,50,51,52,58,59$ & 4 \\
Gubam, PNG & 1 & 60 & 3 \\
135K N, AUS & 1 & 61 & 5 \\
Claudi, AUS & 1 & 62 & 5 \\
Claudie river, AUS & 2 & 64,65 & 10 \\
\hline
\end{tabular}

Note: PNG, Papua New Guinea; WP, West Province Papua New Guinea; AUS, Australia.

This study involved measuring a total of 278 trees, encompassing the magnitude of growth characteristics (D and $\mathrm{H}$ ) and wood properties (P and SWV) at 6-year-old. In addition, D was measured at $1.3 \mathrm{~m}$ above the ground level, with the aid of a diameter tape (F10-02DM, KDS, Japan), while $\mathrm{H}$ was determined using an altimeter (Haga, Germany). Furthermore, $\mathrm{P}$ was assessed with a Pilodyn tester (6 J Forest, Proceq, Switzerland) at $1.3 \mathrm{~m}$ above ground level, where three replicates were obtained for each tree (Ishiguri et al., 2008; Hidayati et al., 2013a;b), and their barks were not peeled. Meanwhile, within this progeny test site, nine specimens were felled for other studies (anatomical, physical, and mechanical properties), where the mean value of the bark thickness was $5.15 \mathrm{~mm}$ (four points of the bark were measured for each tree), and $\mathrm{P}$ was, further, assessed. Fig. 1 shows a negative relationship between $\mathrm{P}$ and basic density, which is, therefore, a good indicator for predicting the basic density values of $A$. mangium. Conversely, the SWV of the stem were measured using a commercial hand-held stress wave timer (FAKKOP Microsecond Timer, FAKKOP Enterprise, Hungary), applying the method of Ishiguri et al. (2007), where start sensors set at $150 \mathrm{~cm}$ from ground level was hit with a small hammer, in an attempt to create the stress wave, which the stop sensor, placed at $50 \mathrm{~cm}$, receives, and the propagation time between

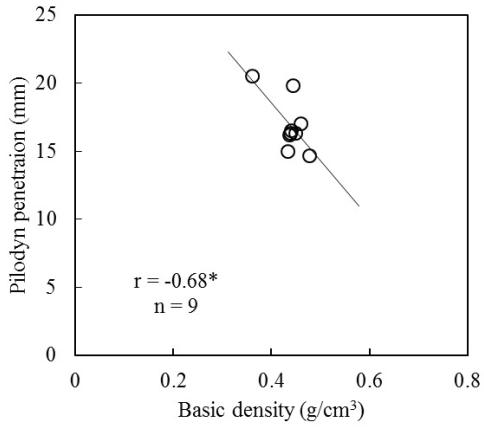

Fig. 1. Relationship between Pilodyn penetration and the basic density of Acacia mangium. * indicates significance at the $5 \%$ level.

the two was recorded. In addition, eight measurements were obtained, and their mean value was calculated for each tree, therefore, SWV was computed by dividing the value obtained with the distance between $(100 \mathrm{~cm})$.

Analyses of variance (ANOVA) were performed to evaluate the differences in $\mathrm{D}, \mathrm{H}, \mathrm{P}$, and SWV among the tested families, and the following model was used for each character:

$$
Y_{i j}=\mu+F_{j}+\varepsilon_{i j}
$$

where $Y_{i j}$ denotes the response of the $j$-th family in the $i$-th replication, $\mu$ depicts the overall mean, $F_{j}$ the genetic effect of the $j$-th family, $\varepsilon_{i j}$ was the error 
associated with $Y_{i j}$. Furthermore, the narrow-sense family heritability of growth characteristics and wood properties estimated using the following formula, which assesses the magnitude of genetic effects:

$$
h_{f}^{2}=\sigma_{f}^{2} /\left[\sigma_{f}^{2}+\left(\sigma_{e}^{2} / \mathrm{R}\right)\right]
$$

where $h_{f}^{2}$ signifies the narrow-sense family heritability, $\sigma_{f}^{2}$ denotes their variance component, $\sigma_{e}^{2}$ was the variance component of the error, and $\mathrm{R}$ symbolizes block. Moreover, due to the fact that the tested families are half sib, the narrow-sense value obtained was applied in the calculation of heritability.

\section{RESULTS and DISCUSSION}

Table 2 shows the mean values of stem diameter $(\mathrm{D})$, tree height $(\mathrm{H})$, Pilodyn penetration $(\mathrm{P})$, and stress-wave velocity (SWV) observed at the thirdgeneration progeny trial of $A$. mangium, where the mean values in each family were $12.7-22.5 \mathrm{~cm}, 13.7-23.1$ m, 15.7-18.9 mm, and 3,238 - 3,627 m/s, respectively.

The results of ANOVA and narrow-sense family heritability are shown in Table 3, and significant differences were observed in all measured characteristics, amongst the 65 families. Hai et al. (2015) reported that D and $\mathrm{H}$ showed significant differences between 112 families of 4-year-old A. mangium, planted in $\mathrm{Ba} \mathrm{Vi}$, and $\mathrm{P}$ were substantially different amid 112 of 4-year-old, 70 families 3-year-old in Tuyen, and 100 families 3-yearold in Bau Bang, Vietnam. Furthermore, it was also reported that dynamic modulus elasticity $\left(\mathrm{MOE}_{\mathrm{d}}\right)$ exhibited a significant difference amongst the 100 families of 3-year-old A. mangium planted in Bau Bang, while Pelletier et al. (2008) stated the D and H of 104-monthold Eucalyptus pilularis planted in Australia to be significantly different amongst 308 families. In addition, $\mathrm{D}, \mathrm{H}, \mathrm{P}$, and SWV were considerably dissimilar between 19 clones of Eucalyptus hybrid planted in China (Wu et al., 2011a), 21 seed provenances of 24-year-old teak planted in Indonesia (Hidayati et al., 2013a), and also among 15 clones of 12-year-old teak planted and two distinctive sites (Hidayati et al., 2013b). Furthermore, the results obtained were consistent with those in previous studies (Hai et al., 2015; Pelletier et al., 2008; Wu et al., 2011a; Hidayati et al., 2013a,b), hence, it is considered that growth characteristics and wood properties are genetically controlled in A. mangium.

Hai et al. (2015) reported the narrow-sense heritability of $\mathrm{D}, \mathrm{H}$, and $\mathrm{P}$ to be $0.26,0.22$, and 0.25 , respectively for the 4-year-old planted tree in $\mathrm{Ba} \mathrm{Vi}$. Meanwhile, in Tuyen Quang, their values including that of $\mathrm{MOE}_{\mathrm{d}}$ were $0.27,0.24,0.21$, and 0.15 , respectively for the 3-year-old specimen. Furthermore, it was also reported to be $0.14,0.30$, and 0.22 , for $\mathrm{D}, \mathrm{H}$, and $\mathrm{P}$ respectively in 3-year-olds at Bau Bang (Hai et al., 2015). In addition, the values obtained for 104-monthold E. pilularis planted in Australia were 0.20 and 0.27 for $\mathrm{D}$ and $\mathrm{H}$, respectively (Pelletier et al., 2008), while broad-sense heritability of $\mathrm{D}, \mathrm{H}, \mathrm{P}$, and SWV were $0.27,0.27,0.23$, and 0.24 , respectively of 24-year-old teak provenances in Indonesia (Hidayati et al., 2013a). Furthermore, this was also estimated for 12-year-old teak clones, planted at two different sites in Cepu to be $0.50,0.39,0.65$, and 0.30 respectively for $\mathrm{D}, \mathrm{H}$, $\mathrm{P}$, and SWV, while those planted in Ciamis were 0.76, $0.44,0.60$, and 0.27 , respectively (Hidayati et al., 2013b). Furthermore, low to moderate values were obtained in the present study (Table 3), indicating a potential for improving growth characteristics and wood properties in A. mangium, through breeding programs. Moreover, the heritability of SWV was observed to be slightly higher than Pilodyn penetration $\left(h_{i}^{2}=0.27\right)$, suggesting it to be the most important criteria in selecting trees for construction and furniture purpose. Furthermore, the heritability values obtained were higher than what was recorded in prior research (Hai et al., 2015), suggesting its ability to increase with tree age. 
Variation in Tree Growth Characteristics, Pilodyn Penetration, and Stress-wave Velocity in 65 Families of Acacia mangium Trees Planted in Indonesia

Table 2. Mean values of growth characteristics, pilodyn penetration, and stress-wave velocity of each family in 6-year-old of third-generation progeny trial of Acacia mangium

\begin{tabular}{|c|c|c|c|c|c|c|c|c|c|}
\hline \multirow{2}{*}{$\begin{array}{c}\text { Family } \\
\text { code }\end{array}$} & \multirow{2}{*}{$\begin{array}{c}\text { Number of } \\
\text { trees }\end{array}$} & \multicolumn{2}{|c|}{$\mathrm{D}(\mathrm{cm})$} & \multicolumn{2}{|c|}{$\mathrm{H}(\mathrm{m})$} & \multicolumn{2}{|c|}{$\mathrm{P}(\mathrm{mm})$} & \multicolumn{2}{|c|}{ SWV (m/s) } \\
\hline & & Mean & $\mathrm{SD}$ & Mean & $\mathrm{SD}$ & Mean & $\mathrm{SD}$ & Mean & $\mathrm{SD}$ \\
\hline 1 & 4 & 19.1 & 1.42 & 18.5 & 2.67 & 16.0 & 1.42 & 3,227 & 223 \\
\hline 2 & 5 & 21.7 & 3.03 & 19.9 & 2.12 & 18.2 & 3.03 & 3,342 & 85 \\
\hline 3 & 4 & 18.6 & 1.83 & 19.9 & 2.29 & 17.1 & 1.83 & 3,456 & 278 \\
\hline 4 & 3 & 15.7 & 1.84 & 13.7 & 3.92 & 16.9 & 1.84 & 3,340 & 142 \\
\hline 5 & 5 & 20.1 & 3.01 & 19.4 & 2.58 & 16.5 & 3.01 & 3,583 & 164 \\
\hline 6 & 4 & 21.1 & 2.14 & 20.6 & 3.21 & 18.0 & 2.14 & 3,497 & 170 \\
\hline 7 & 5 & 18.9 & 3.04 & 19.9 & 0.74 & 17.6 & 3.04 & 3,525 & 158 \\
\hline 8 & 4 & 15.7 & 1.00 & 15.0 & 2.84 & 18.7 & 1.00 & 3,238 & 77 \\
\hline 9 & 5 & 18.9 & 3.30 & 18.5 & 2.92 & 17.8 & 3.30 & 3,466 & 220 \\
\hline 10 & 4 & 16.0 & 2.29 & 17.6 & 1.17 & 18.0 & 2.29 & 3,404 & 63 \\
\hline 11 & 3 & 17.0 & 3.34 & 20.3 & 2.27 & 16.7 & 3.34 & 3,445 & 328 \\
\hline 12 & 5 & 19.5 & 1.90 & 20.1 & 3.19 & 17.1 & 1.90 & 3,291 & 260 \\
\hline 13 & 3 & 19.3 & 1.79 & 18.8 & 1.08 & 16.8 & 1.79 & 3,411 & 109 \\
\hline 14 & 3 & 16.6 & 3.89 & 19.7 & 2.97 & 17.3 & 3.89 & 3,318 & 224 \\
\hline 15 & 5 & 19.2 & 3.33 & 16.9 & 3.59 & 16.4 & 3.33 & 3,604 & 119 \\
\hline 16 & 5 & 22.1 & 1.92 & 20.6 & 2.09 & 18.0 & 1.92 & 3,241 & 163 \\
\hline 17 & 4 & 21.9 & 1.88 & 20.5 & 3.78 & 18.5 & 1.88 & 3,358 & 159 \\
\hline 18 & 4 & 18.0 & 2.03 & 19.6 & 2.50 & 18.0 & 2.03 & 3,459 & 306 \\
\hline 19 & 4 & 20.7 & 1.16 & 21.0 & 3.42 & 16.6 & 1.16 & 3,287 & 163 \\
\hline 20 & 4 & 20.9 & 2.75 & 23.1 & 0.76 & 17.6 & 2.75 & 3,627 & 157 \\
\hline 21 & 3 & 12.7 & 1.59 & 11.0 & 1.30 & 18.3 & 1.59 & 3,170 & 157 \\
\hline 22 & 3 & 18.3 & 3.25 & 18.3 & 2.97 & 17.6 & 3.25 & 3,433 & 354 \\
\hline 23 & 5 & 19.3 & 2.77 & 18.2 & 3.82 & 18.0 & 2.77 & 3,432 & 205 \\
\hline 24 & 4 & 19.2 & 1.00 & 23.0 & 4.86 & 17.3 & 1.00 & 3,366 & 30 \\
\hline 25 & 5 & 20.6 & 2.88 & 18.5 & 3.41 & 18.6 & 2.88 & 3,267 & 148 \\
\hline 26 & 5 & 19.3 & 4.27 & 19.2 & 3.40 & 17.5 & 4.27 & 3,365 & 129 \\
\hline 27 & 4 & 19.8 & 3.16 & 20.6 & 3.42 & 17.3 & 3.16 & 3,514 & 90 \\
\hline 28 & 4 & 19.3 & 2.00 & 20.8 & 2.51 & 16.4 & 2.00 & 3,489 & 195 \\
\hline 29 & 5 & 18.4 & 1.81 & 20.0 & 1.04 & 17.0 & 1.81 & 3,521 & 93 \\
\hline 30 & 5 & 19.1 & 3.07 & 19.6 & 2.29 & 16.0 & 3.07 & 3,571 & 96 \\
\hline 31 & 3 & 17.3 & 2.95 & 17.8 & 3.91 & 18.4 & 2.95 & 3,365 & 199 \\
\hline 32 & 5 & 21.0 & 1.55 & 20.0 & 2.47 & 16.4 & 1.55 & 3,482 & 105 \\
\hline 33 & 4 & 22.3 & 2.13 & 21.5 & 1.65 & 17.5 & 2.13 & 3,386 & 110 \\
\hline 34 & 5 & 18.9 & 2.86 & 19.7 & 1.53 & 17.2 & 2.86 & 3,584 & 76 \\
\hline 35 & 4 & 19.9 & 2.82 & 19.5 & 3.84 & 17.3 & 2.82 & 3,581 & 280 \\
\hline 36 & 5 & 17.7 & 3.08 & 18.3 & 2.50 & 17.1 & 3.08 & 3,515 & 118 \\
\hline 37 & 4 & 17.5 & 2.49 & 16.8 & 4.25 & 18.0 & 2.49 & 3,357 & 171 \\
\hline 38 & 4 & 18.1 & 2.23 & 18.8 & 1.85 & 17.3 & 2.23 & 3,359 & 104 \\
\hline 39 & 5 & 16.9 & 1.22 & 18.5 & 4.03 & 18.2 & 1.22 & 3,541 & 176 \\
\hline 40 & 5 & 17.4 & 1.04 & 18.0 & 4.02 & 16.5 & 1.04 & 3,504 & 214 \\
\hline 41 & 4 & 20.3 & 2.06 & 18.0 & 1.39 & 16.3 & 2.06 & 3,397 & 344 \\
\hline
\end{tabular}


Table 2. (Continued)

\begin{tabular}{|c|c|c|c|c|c|c|c|c|c|}
\hline \multirow{2}{*}{$\begin{array}{c}\text { Family } \\
\text { code }\end{array}$} & \multirow{2}{*}{$\begin{array}{c}\text { Number of } \\
\text { trees }\end{array}$} & \multicolumn{2}{|c|}{$\mathrm{D}(\mathrm{cm})$} & \multicolumn{2}{|c|}{$\mathrm{H}(\mathrm{m})$} & \multicolumn{2}{|c|}{$\mathrm{P}(\mathrm{mm})$} & \multicolumn{2}{|c|}{ SWV (m/s) } \\
\hline & & Mean & SD & Mean & SD & Mean & SD & Mean & $\mathrm{SD}$ \\
\hline 42 & 5 & 22.5 & 1.87 & 21.6 & 4.73 & 17.0 & 1.87 & 3,497 & 170 \\
\hline 43 & 5 & 19.2 & 1.13 & 16.5 & 3.72 & 18.9 & 1.13 & 3,406 & 147 \\
\hline 44 & 4 & 17.2 & 3.11 & 17.8 & 2.00 & 18.0 & 3.11 & 3,402 & 315 \\
\hline 45 & 3 & 17.6 & 2.18 & 18.3 & 2.02 & 15.7 & 2.18 & 3,456 & 129 \\
\hline 46 & 5 & 18.9 & 0.99 & 19.2 & 2.97 & 16.6 & 0.99 & 3,473 & 311 \\
\hline 47 & 4 & 18.7 & 3.63 & 17.6 & 3.76 & 16.4 & 3.63 & 3,454 & 197 \\
\hline 48 & 4 & 18.7 & 3.21 & 18.4 & 2.75 & 17.8 & 3.21 & 3,323 & 218 \\
\hline 49 & 5 & 19.7 & 2.37 & 19.5 & 2.22 & 17.8 & 2.37 & 3,513 & 79 \\
\hline 50 & 5 & 20.0 & 1.82 & 21.1 & 1.38 & 16.8 & 1.82 & 3,449 & 229 \\
\hline 51 & 3 & 17.9 & 1.39 & 21.3 & 2.87 & 16.7 & 1.39 & 3,572 & 118 \\
\hline 52 & 5 & 20.7 & 1.89 & 20.6 & 2.92 & 17.4 & 1.89 & 3,540 & 172 \\
\hline 53 & 4 & 19.0 & 2.13 & 18.4 & 1.85 & 16.4 & 2.13 & 3,598 & 127 \\
\hline 54 & 4 & 18.4 & 2.46 & 19.9 & 1.82 & 16.2 & 2.46 & 3,567 & 152 \\
\hline 55 & 3 & 17.6 & 2.44 & 20.0 & 3.07 & 16.7 & 2.44 & 3,312 & 104 \\
\hline 56 & 4 & 20.2 & 2.81 & 18.4 & 3.23 & 17.6 & 2.81 & 3,331 & 177 \\
\hline 57 & 4 & 20.0 & 2.93 & 22.4 & 3.18 & 17.6 & 2.93 & 3,377 & 121 \\
\hline 58 & 5 & 18.8 & 3.30 & 19.8 & 3.88 & 16.8 & 3.30 & 3,536 & 122 \\
\hline 59 & 5 & 18.6 & 0.45 & 19.5 & 2.53 & 16.1 & 0.45 & 3,396 & 76 \\
\hline 60 & 4 & 18.6 & 1.71 & 19.3 & 3.95 & 18.3 & 1.71 & 3,435 & 187 \\
\hline 61 & 3 & 16.2 & 1.35 & 14.5 & 3.80 & 18.6 & 1.35 & 3,526 & 65 \\
\hline 62 & 5 & 19.9 & 0.68 & 21.4 & 0.50 & 17.5 & 0.68 & 3,449 & 50 \\
\hline 63 & 5 & 19.1 & 1.80 & 18.5 & 1.26 & 18.2 & 1.80 & 3,375 & 138 \\
\hline 64 & 5 & 18.4 & 4.28 & 20.5 & 1.50 & 16.2 & 4.28 & 3,497 & 110 \\
\hline 65 & 5 & 18.5 & 2.52 & 19.0 & 3.32 & 18.2 & 2.52 & 3,300 & 122 \\
\hline
\end{tabular}

Note: D, stem diameter; H, tree height; P, Pilodyn penetration; SWV, stress-wave velocity; SD, Standard deviation

Table 3. Results of analysis of variance (ANOVA) and narrow-sense heritability of the measured characteristics in third-generation progeny trial of Acacia mangium

\begin{tabular}{ccccccc}
\hline Characteristic & Mean & SD & $\begin{array}{c}\text { Significance among } \\
\text { families }\end{array}$ & $\begin{array}{c}\text { Variance of } \\
\text { families }\end{array}$ & $\begin{array}{c}\text { Variance of } \\
\text { environment }\end{array}$ & Heritability \\
\hline \hline D (cm) & 18.9 & 1.74 & $0.0002^{*}$ & 1.395 & 5.929 & 0.41 \\
H (m) & 19.1 & 2.03 & $0.0008^{*}$ & 1.641 & 8.328 & 0.37 \\
P (mm) & 17.3 & 0.79 & $0.0272^{*}$ & 0.197 & 1.839 & 0.25 \\
SWV (m/s) & 3,432 & 105 & $0.0144^{*}$ & 4,205 & 33,640 & 0.27 \\
\hline
\end{tabular}

Note: D, stem diameter; H, tree height; P, Pilodyn penetration; SWV, stress-wave velocity; SD, standard deviation;

*, significance at the $5 \%$ level.

Meanwhile, it was reported in teak that narrow-sense heritability of $\mathrm{D}$ and $\mathrm{H}$ gradually increased at an exponent of age (Monteuuis et al., 2011).
Highly positive significant correlations were established between $\mathrm{D}$ and $\mathrm{H}$ in the present study (Fig. 2), and also for other hardwood species observed in 
Variation in Tree Growth Characteristics, Pilodyn Penetration, and Stress-wave Velocity in 65 Families of Acacia mangium Trees Planted in Indonesia

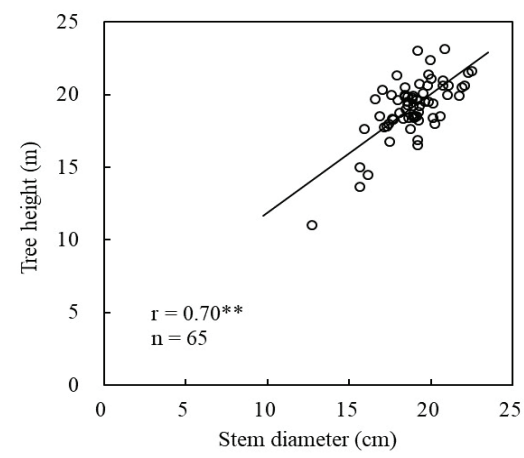

Fig. 2. Relationship between stem diameter and tree height in third-generation progeny trial of Acacia mangium. ${ }^{* *}$ indicate significance at the $1 \%$ level.

previous research (Kha et al., 2012; Callister and Collins, 2008; Monteuuis et al., 2011; Chaix et al., 2011; Hidayati et al., 2013a, b; Hidayati et al., 2017). This result suggests growth characteristics to be closely related to one another in A. mangium trees.

Generally, a substantial negative association was discovered between $\mathrm{P}$ and wood density (Moura et al., 1987; Wei and Borralho, 1997; Wu et al., 2010, 2011b). Kojima et al. (2009) reported no correlation concerning xylem density and lateral growth rate in A. mangium planted in Malaysia. In addition, minimal positive correlations were observed amongst growth characteristics (D and $\mathrm{H}$ ) and $\mathrm{P}$ in E. urophylla planted in China (Wei and Boralho, 1997), while moderate to high levels were found in other hardwood species (Wu et al., 2011b; Hidayati et al., 2013a, b), and the present study showed no significant correlations (Fig. 3 \& 4). These results are consistent with previous outcomes (Kojima et al., 2009; Wei and Boralho, 1997), suggest that $\mathrm{P}$ is independent of growth characteristics in $A$. mangium.

Fig. 5 and 6 illustrate the relationships between growth characteristics and SWV. Stress-wave velocity of standing trees was to be significantly positive correlation to DMOE (dynamic modulus of elasticity) of logs or MOE of small clear specimens (Wang et

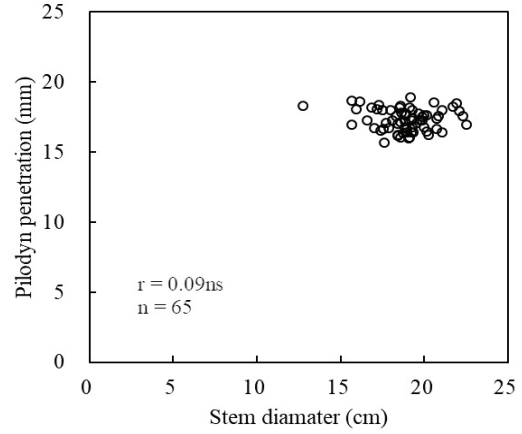

Fig. 3. Relationship between stem diameter and Pilodyn penetration in third-generation progeny trial of Acacia mangium. ns indicates non-significance.

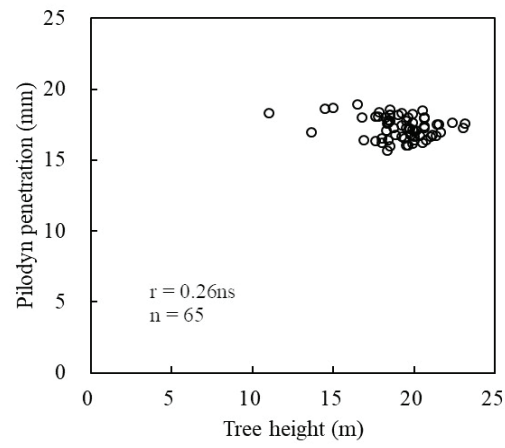

Fig. 4. Relationship between tree height and Pilodyn penetration in third-generation progeny trial of Acacia mangium. ns indicates non-significance.

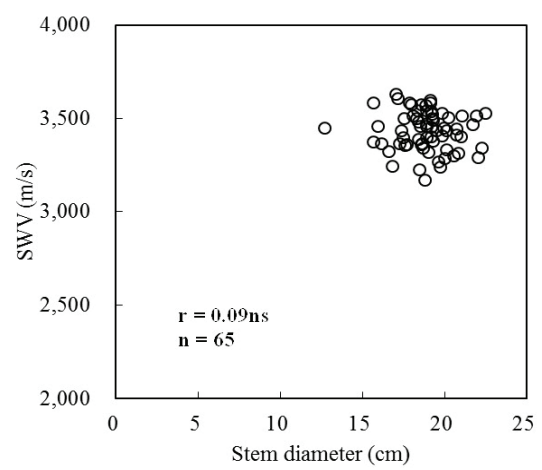

Fig. 5. Relationship between stem diameter and SWV in third-generation progeny trial of Acacia mangium. ns indicates non-significance. 


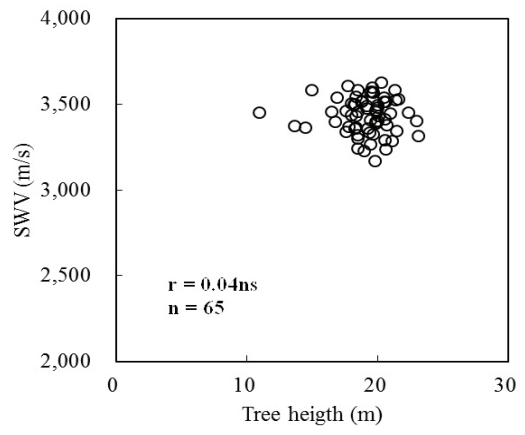

Fig. 6. Relationship between tree height and SWV in third-generation progeny trial of Acacia mangium. ns indicates non-significance.

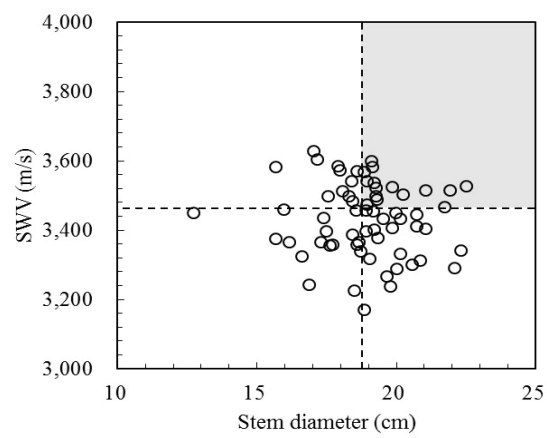

Fig. 7. Family grouping according to the mean value of stem diameter and SWV, indicated by the dotted line, while the grey color area shows a high value.

al., 2001; Ishiguri et al., 2013). Furthermore, D negatively correlates, though slightly, with DMOE (Hai et al., 2015), while Makino et al. (2012) reported no significant correlation to occur in those planted within Indonesia. In addition, other hardwood species showed no sgnificant correlation between growth characteristics (D and $\mathrm{H}$ ) and SWV, which was also attested by other reports (Dickson et al., 2003; Ishiguri et al., 2011; Hidayati et al., 2013a, b; Hidayati et al., 2017). Moreover, these study outcomes are consistent with previous results (Hai et al., 2015; Makino et al., 2012; Dickson et al., 2003; Ishiguri et al., 2011; Hidayati et al., 2013a, b; Hidayati et al., 2017). Therefore, it can be concluded that physical and mechanical properties are also important characters for the selection criteria within breeding programs, and SWV (which is mechanical) seems to be the most important.

D and SWV showed higher values for heritability, in comparison with $\mathrm{H}$ and $\mathrm{P}$ (Table 3), therefore, a group of the family was made in accordance with these two characteristics (Fig. 7), where 18 showed high performance (above the mean values), including Family $3,6,7,9,11,27,28,29,35,36,39,40,46,47,50$, 53,58 , and 61 . These could be considered as plus trees for the next generation breeding cycles for improving growth and wood properties of A. mangium.

\section{CONCLUSION}

Characterization of variations in tree growth (D and $\mathrm{H}$ ) and wood properties ( $\mathrm{P}$ and SWV) were conducted in third-generation progeny trials of $A$. mangium in Indonesia, which were observed to vary among families. Furthermore, narrow-sense heritability of these evaluated characteristics was low to moderate, which is suggestive of genetic control. Meanwhile, highly positive correlations were observed between the growth characteristics, but no significant correlations were established with wood properties ( $\mathrm{P}$ and SWV). Therefore, it is possible to improve breeding programs for $A$. mangium through the involvement of the analyzed parameters, independently, as the important criteria for selection. In addition, 18 families showed the high performance of D and SWV, suggesting them to be considered as a plus tree for the next generation breeding cycles.

\section{ACKNOWLEDGMENT}

The authors thank the Ministry of Research and Technology, The Republic of Indonesia for the PUPT grant (Letter of Assignment of Work Implementation Number: 2427/UN1-P.III/DIT-LIT/LT/2017, and the 
Variation in Tree Growth Characteristics, Pilodyn Penetration, and Stress-wave Velocity

in 65 Families of Acacia mangium Trees Planted in Indonesia

addendum Number: 7381/UN1.P.III/DIT.LIT/LT/2017), for this research. In addition, the authors also thank the Center for Forest Biotechnology and Tree Improvement, Ministry of Forestry, the Republic of Indonesia for providing sample trees.

\section{REFERENCES}

Arisman, H. 2002 Sustainable acacia plantations: a case of short-rotation plantation at PT. Musi Hutan Persada, South Sumatra, Indonesia In: Rimbawanto, A. and Susanto, M. (eds) Advances in genetic improvement of tropical tree species, 9-13. Indonesian Ministry of Forestry Research and Development Agency and Japan International Cooperation Agency, Yogyakarta, Indonesia, pp. 9-13

Callister, A.N., Collins, S.L. 2008. Genetic parameter estimates in a clonally replicated progeny test of teak (Tectona grandis Linn. f.). Tree Genetics and Genomes 4(2): 237-245.

Chaix, G., Monteuuis, O., Garcia, C., Alloysius, D., Gidiman, J., Bacilieri, R., Goh, D.K.S. 2011. Genetic variation in major phenotypic traits among diverse genetic origins of teak (Tectona grandis L.f) planted in Taliwas, Sabah, East Malaysia. Annals of Forest Science 68(5): 1015-102.

Darmawan, W., Nandika, D., Afaf, B.D.H., Rahayu, I., Lumongga, D. 2018. Radial variation in selected wood properties of Indonesia merkusii pine. Journal of the Korean Wood Science and Technology 46(4): 323-337.

Dickson, R.L., Raymond, C.A., Joe, W., Wilkinson, C.A. 2003. Segregation of Eucalyptus dunnii logs using acoustics. Forest Ecology and Management 179(1-3): 243-251.

Fujimoto, T., Akutsu, H., Takizawa, T. 2002. Several wood properties of plantation-grown Acacia species. Journal of the Hokkaido Forest Products
Research Institute 16: 6-10.

Hai, P.H., Duong, L.A., Toan, N.Q., Ha, T.T.T. 2015. Genetic variation in growth, stem straightness, pilodyn and dynamic modulus of elasticity in second-generation progeny test of Acacia mangium at three sites in Vietnam. New Forests 46(4): 577-591.

Hai, P.H., Jansson, G., Harwood, C., Hannrup, B., Thinh, H.H. 2008. Genetic variation in growth, stem straightness and branch thickness in clonal trials of Acacia auriculiformis at three contrasting sites in Vietnam. Forest Ecology and Management 255(1): 156-167.

Hansen, C.P. 2000. Aplication of the pilodyn in forest tree improvement. Danida Forest Seed Center, Humlebaek, pp 1-11.

Hidayat, W., Kim, Y.K., Jeon, W.S., Lee, J.A., Kim, A.R., Park, S.H., Maail, R.S., Kim, N.H. 2017. Qualitative and quantitative anatomical characteristics of four tropical wood species from Moluccas, Indonesia. Journal of the Korean Wood Science and Technology 45(4): 369-381.

Hidayati, F., Ishiguri, F., Makino, K., Tanabe, J., Aiso, H., Prasetyo, V.E., Marsoem, S.N., Wahyudi, I., Iizuka, K., Yokota, S. 2017a. The effects of radial growth rate on wood properties and anatomical characteristics and an evaluation of the xylem maturation process in a tropical fast-growing tree species, Gmelian arborea. Forest Products Journal 67(3/4): 297-303.

Hidayati, F., Ishiguri, F., Marsoem, S.N. 2017b. Anatomical characteristics and air-dry density of young trees of teak clones planted in Indonesia. Journal of the Korean Wood Science and Technology 45(4): 403-470.

Hidayati, H., Ishiguri, F., Iizuka, K., Makino, K., Takashima, Y., Danarto, S., Winarni, W.W., Irawati, D., Na iem, M., Yokota, S. 2013a.Variation in tree growth characteristics, stress-wave velocity, 
Fanny HIDAYATI • Ganis LUKMANDARU • Sapto INDRIOKO • Sri SUNARTI • Arif NIRSATMANTO

and Pilodyn penetration of 24-year-old teak (Tectona grandis) trees originating in 21 seed provenances planted in Indonesia. Journal of Wood Science 59(6): 512-516.

Hidayati, H., Ishiguri, F., Iizuka, K., Makino, K., Tanabe, J., Marsoem, S.N., Na`iem, M., Yokota, S., Yoshizawa, N. 2013b. Growth characteristics, stress-wave velocity, and Pilodyn penetration of 15 clones of 12-year-old Tectona grandis trees planted at two different sites in Indonesia. Journal of Wood Science 59(3): 249-254.

Honjo, K., Furukawa, I., Sahri, M.H. 2005. Radial variation of fiber length increment in Acacia mangium. IAWA Journal. 26(3): 339-352.

Ishiguri, F., Diloksumpun, S., Tanabe, J., Iizuka, K., Yokota, S. 2013 Stress-wave velocity of trees and dynamic Young's modulus of logs of 4-year-old Eucalyptus camaldulensis trees selected for pulpwood production in Thailand. Journal of Wood Science 59: 506-511

Ishiguri, F., Eizawa, J., Saito, Y., Iizuka, K., Yokota, S., Priadi, D., Sumiasri, N., Yoshizawa, N. 2007. Variation in the wood properties of Paraserianthes falcataria planted in Indonesia. IAWA Journal 28(3): 339-348.

Ishiguri, F., Matsui, R., Iizuka, K., Yokota, S., Yoshizawa, N. 2008. Prediction of the mechanical properties of lumber by stress-wave velocity and Pilodyn penetration of 36-year-old Japanese larch trees. Holz Roh Werkst 66: 275-280

Ishiguri, F., Wahyudi, I., Takeuchi, M., Takashima, Y., Iizuka, K., Yokota, S., Yoshizawa, N. 2011. Wood properties of Pericopsis mooniana grown in a plantation in Indonesia. Journal of Wood Science 57(3): 241-246.

Iswanto, A.H., Susilowati, A., Azhar, I., Riswan, Supriyanto, Tarigan, J.E., Fatriasari, W. 2016. Physical and mechanical properties of local styrac wood from North Tapanuli in Indonesia. Journal of the Korean Wood Science and Technology 44(4): 539-550.

Jeong, H.M., Kim, Y., Kim, J.Y., Seo, J.W. 2016. Tree-ring dating of the Palsangjeon wooden pagoda Beopjusa temple in Boeun, South Korea. Journal of the Korean Wood Science and Technology 44(4): 515-525.

Kha, L.D., Harwood C.E., Kien, N.D., Baltunis, B.S., Hai, N.D., Thinh, H.H. 2012. Growth and wood basic density of acacia hybrid clones at three locations in Vietnam. New Forests 43(1): 13-29.

Kim, N. T., Matsumura, J., Oda, K., Cuong, N.V. 2009. Possibility of improvement in fundamental properties of wood of acacia hybrids by artificial hybridization. Journal of Wood Science 55(1): 8-12.

Kojima, M., Yamamoto, H., Okumura, K., Ojio, Y., Yoshida, M., Okuyama, T., Ona, T., Matsune, K., Nakamura, K., Ide, Y., Marsoem, S.N., Sahri, M.H., Hadi, Y.S. 2009. Effect of the lateral growth rate on wood properties in fast-growing hardwood species. Journal of Wood Science 55(6): 417-424.

Makino, K., Ishiguri, F., Wahyudi, I., Takashima, Y., Iizuka, K., Yokota, S., Yoshizawa, N. 2012. Wood properties of young Acacia mangium trees planted in Indonesia. Forest Products Journal 62(2): 102-106.

Marsoem, S.N. 2004. Utilization of Acacia mangium from Plantation Forest. In E. B. Hardiyanto and H. Arisman (Eds.), Development of Acacia mangium plantation forest: an experience in PT Musi Hutan Persada, South Sumatra. Yogyakarta: Polydoor Press. (In Indonesian)

Matsumoto, K., Ishiguri, I., Wahyudi, I., Takashima, Y., Shimizu, K., Iizuka, K., Yokota, S., Yoshizawa, N. 2010. Application of Fractometer for wood property evaluation in five Indonesian plantation species. Bulletin of the Utsunomiya University Forests 46: 1-6.

Monteuuis, O., Goh, D.K.S., Garcia, C., Alloysius, D., 
Variation in Tree Growth Characteristics, Pilodyn Penetration, and Stress-wave Velocity in 65 Families of Acacia mangium Trees Planted in Indonesia

Gidiman, J., Bacilieri, R., Chaix, G. 2011. Genetic variation of growth and tree quality traits among 42 diverse genetic origins of Tectona grandis planted under humid tropical conditions in Sabah, East Malaysia. Tree Genetics and Genomes 7(6): 1263-1275.

Moura, V.P.G., Barnes, R.D., Birks, J.S. 1987. A comparison of three methods of assessing wood density in provenances of Eucalyptus camaldulensis Dehnh. and other Eucalyptus species in Brazil. Australian Forest Research 17: 83-90.

Muneri, A., Raymond, C.A. 2000. Genetic parameters and genotype-by-environment interactions for basic density, pilodyn penetration and stem diameter in Eucalyptus globulus. Forest Genetics 7(4): 317-328. Nugroho, W.D., Marsoem, S.N., Yasue, K., Fujiwara, T., Nakajima, T., Hayakawa, M., Nakaba, S., Yamagishi, Y., Jin, H.O., Kubo, T., Funada, R. 2011. Radial variations in the anatomical characteristics and density of the wood of Acacia mangium of five provenances in Indonesia. Journal of Wood Science 58(3): 185-194.

Pelletier, M.C., Henson, M., Boyton, S., Thomas, D., Vanclay, J.K. 2008. Genetic variation in shrinkage properties of Eucalyptus pilularis assessed using increment cores and test blocks. New Zealand Journal of Forestry Science 38(38): 194-210.

Rofii, M.N., Prayitno, T.A., Suzuki, S. 2016. Dynamic modulus of three layer boards with different furnish and shelling ratio. Journal of Korean Wood Science and Technology 44(2): 274-282.

Ross, R.J., McDonald, K.A., Green, D.W., Schad, K.C. 1997. Relationship between log and lumber modulus of elasticity. Forest Products Journal 47: 89-92

Sprague, J.R., Talbert, J.T., Jett, J.B., Bryan, R.L. 1983. Utility of the Pilodyn in selection for mature wood spesific gravity in loblolly pine. Forest Science 29(4): 696-701
Sunarti, S., Nirsatmanto, A., Setyaji, T., Kartikaningtyas, D., Yuliastuti, D.S., Surip. 2012. General information of seed source (F-3) of Acacia mangium establishment in Central Java. Forestry Research and Development Agency. Ministry of Forestry in Indonesia.

Taylor, F.W. 1981. Rapid determination of southern pine specific gravity with a pilodyn tester. Forest Science 27(1): 59-61

Wang, X., Ross, R.J., McClellan, M., Barbour, R.J., Erickson, J.R., Forsman, J.W., McGinnis, G.D. 2001. Nondestructive evaluation of standing trees with a stress wave method. Wood and Fiber Science 33(4): 522-533.

Wei, X., Borralho, N.M.G. 1997. Genetic control of wood basic density and bark thickness and their relationships with growth traits of Eucalyptus urophylla in South East China. Silvae Genetica 46(4): 245-250.

Woods, J.H., Kolotelo, D., Yanchuk, A.D. 1995. Early selection of coastal Douglas-fir in a farm-field test environment. Silvae Genetica 44: 178-186.

Wu, S., Xu, J., Li, G., Risto, V., Du, Z., Lu, Z., Li., B., Wang, W. 2011a. Genotypic variation in wood properties and growth traits of Eucalyptus hybrid clones in southern China. New Forests 42(1): 35-50.

Wu, S.J., Xu, J.M., Li, G.Y., Risto, V., Lu, Z.H., Li, B.Q., Wang, W. 2010. Use of the pilodyn for assessing wood properties in standing trees of Eucalyptus clones. Journal of Forestry Research 21(1): 68-72.

Wu, S.J., Xu, J.M., Li, G.Y., Risto, V., Lu, Z.H., Li, B.Q., Wang, W. 2011b. Estimation on basic density and modulus of elasticity of eucalypt clones in Southern China using non-destructive methods. Journal of Tropical Forest Science 23(1): 51-56.

Zobel, B.J., van Buijtenen, J.P. 1989. Wood variations, its causes and control. Springer-Verlag, Berlin, Heidelberg, Newyork, London, Paris, Tokyo 